\title{
Modeling educational process optimization in the development of individual creativity by extending modality skills of the learners*
}

\author{
E.A. Gafarova ${ }^{1} \bullet$ V.A. Belevitin ${ }^{1} \bullet$ Y.N. Smyrnov $^{2}$ \\ 1 - South Ural State Humanitarian Pedagogical University Chelyabinsk, Russian Federation; \\ 2 - Ugarov Stary OskolTechnological Institute, Moscow Institute of Steel and Alloys, Stary Oskol, Russian Federation
}

Received: 28 August 2017 / Accepted: 28 September 2017

\begin{abstract}
In the paper, model for time optimization of educational process for the purposes of creativity enhancement in the course of learning by students of educational subjects is considered. Creativity enhancement is supposed to be achieved by means of expansion of trainee psycho physiological base, that is, by means of the maximum variety of educational signals modality. The optimization problem is solved in general by creation of the model based on information states and according to the principles of forms synergy for information support of educational process and optimum time balance minimum necessary for significant increase of trainee creativity. The solution of optimization problem makes it possible to estimate a variety of educational signals modality for educational and methodical guidelines, their completeness within the educational module, to find variants of time budget for various pedagogic forms and methods for application in educational process.
\end{abstract}

Keywords: creativity enhancement, expansion of modal experience, information states, patterns of internal representation, modality of educational signals Introduction

The problem of trainee creativity enhancement has been of interest in psychology and pedagogical researches for many years [1-4].

In researches [4, 5-10], interrelation of intelligence, creativity and success (learning ability) is established, these personality characteristics are considered as attributes of united individual mental resource.

Researches $[3,4,6,8,11-13]$ proved importance of individual psycho physiological basis expansion for productive creative activity, and in papers [8, 14-17], it is shown that completing of pattern of internal perceived information representation up to subjective fullness is biologically motivated and, at the same time, it is a necessary condition for resolving of internal contradiction of the creative task.

Earlier, we proposed a provision about creativity enhancement by means of expansion of trainee modal experience [18].

Considering impact of set of information signals modality on the trainee in educational process corresponds to the idea of creative field [5] and, for pedagogical purposes, can be converted into empirical constructs which can be used for creativity enhancement.

Integration of Russian education system into global educational space, including Russia's full participation in Bologna process, enables transition from traditional Russian "lifewide education" paradigm to a new concept of "continuing education throughout life" which is "lifelong education".

Recent socioeconomic transformations in Russia have brought to focus the problem of professional training quality improvement as well as maintaining trans-border education to provide interaction between the working world of and the world of education. The problem solution determines changes in existing professional training system in Russia, actualizes the concept of competency-based approach in professional development, and causes evolutionary shifts in training management.

This approach can open the door to a multitude of new opportunities for the development of innovations in educational establishments which include acquisition of competency-based pedagogical and management technologies, developing practical-oriented approach through combination of professional and educational activities, and use of efficient ways of knowledge generation and transfer based on innovative approaches.

\footnotetext{
* - editorial invited article [на замовлення редакціï]
}

V.A. Belevitin

belevitinva1@cspu.ru
Y.N. Smyrnov

en_smirnov@i.ua 
The development of practical-oriented approach in education, and the advisable combination of professional and educational activities call for implementation of efficient ways of knowledge generation and transfer. One possible tool for this urgent problem solution is e-learning. The global e-learning market nowadays shows significant growth, and, at the beginning of the $21^{\text {st }}$ century, it has reached $\$ 48$ billion [19].

According to Sloan Consortium, in the USA by 2011 year the number of students involved in e-learning at higher education establishments amounted to 6 million. The research based on opinion poll conducted at leading academic institutions showed that students are at least satisfied with e-learning as compared to traditional one [20].

Educational establishments may be to a higher extent involved in e-learning while the price of such online platforms will decrease. Online teaching requires qualified teaching and technical personnel. An e-learning teacher should not only understand the learning material but be capable of using PC and internet technologies. Online education is continuing to grow at some leading research institutes offering distant doctoral degree programs [21].

The development of e-learning has recently occupied attention of such scientists as D. Zhang and others who considered the impact of interactive video on learning effectiveness and e-learning students' satisfaction level [22]. U. M. Krause and some other scientists have reviewed the effects of feedback on e-learning in statistics [23]. D. PalaciosMarqués and other experts considered the problem of electronic educational project management and found out that such projects require specialists with certain pedagogical and technical competencies [24]. R. N. Shaidullin and colleagues have defined advantages of e-learning including flexibility, personalization, interactivity, and adaptability [25]. The Professional-Pedagogic Institute of South Ural State Humanitarian Pedagogical University has launched the 'Development of professional training teachers' information and communication professional competencies in security aspects" project [26] which specifically analyzes the problem of distance educational technologies (DET) safe use.

As one of important problems of modern pedagogic is development and updating of socially important characteristics of the personality, to which creativity belongs as well, problem of school hours optimization for creativity enhancement by expansion of trainees modal experience is also of high importance.

\section{The problem definition}

II.

Requirements of educational standards give guarantees of effective substantial learning, educational process is implemented in the form of regulated information procedures and these procedure forms are determined by forms of learning session carrying out.

For the purpose of individual creativity enhancement, it is necessary to synthesize a set of information educational flows in such a way that they were represented in the maximum modal variety of educational signals.

The aforesaid results in necessity of coordination of separated information processes and optimization of educational time budget for the benefit of planned educational competences forming (knowledge, abilities, learning) with enhancement of individual creativity by expansion of trainees modal experience.

For solution of the mentioned problem with use of formal methods, formulation of number of the principles and conditions is required [27-33]:

principle of synergy of two forms of educational process information support: objective, aimed to development of educational subject, and supporting, directed to expansion of modal experience of trainees;

principle of optimum time balance sufficient for learning of discipline content by trainees in accordance with educational standards and minimum necessary for significant increase of trainees creativity.

We do not consider limitation of number of basic educational signal modalities as in case of real training the synthetic signals of various modality are possible which differ, for example, not only by format (for example, audio format), but also by their fractional characteristics (tone, amplitude, speech speed - for audio modality).

We also intentionally do not define type of educational institution, age of trainees, educational subject, we consider it necessary to simulate optimization problem in the most general conditions.

Use of mentioned above principles and conditions makes it possible to simulate optimization factors of educational activity system for the purpose of enhancement of trainee individual creativity by expansion of trainee modal experience.

As to the problem content, the problem is formulated as follows: for enhancement of individual creativity in the course of educational process, it is necessary to develop methods for integration of polymodal information processes of educational activity and activities for expansion of trainee modal experience.

\section{III.Solution of optimization problem}

IV.

For the problem and its solution formalization in accordance with principles formulated above, we will determine an ensemble of information states $Z=\left\{z_{i}\left|z_{i} \in Z, i=1,2, \ldots,\right| Z \mid\right\}$ which characterizes consecutive change of 
creativity level in the course of creation of educational competences components; and ensemble $M=\left\{y_{m} \mid y_{m} \in M, m=1\right.$, $2, \ldots,|M|\}$ of psychophysiological impacts of various modality.

Let us put in correspondence to each element $z_{i}$ of ensemble $Z$ an element $y_{m}$ of impact ensemble $M$.

For each educational subject we will determine an ensemble:

$$
\stackrel{u}{F_{m}}=\left\{\stackrel{u}{f_{m j}}\left|\stackrel{u}{f_{m j}} \in \stackrel{u}{F_{m}}, m=1,2, \ldots,\right| M|, j=1,2, \ldots,| \stackrel{u}{F}_{m} \mid\right\}
$$

of informative signs of educational signals expressed in various modalities. Besides, for all set of ensembles $\cap \stackrel{u}{F}_{m}$, (from $m=1$ to $|M|)$ we will determine an ensemble:

$$
\left.\tilde{F}=\left\{\tilde{f}_{j}\left|\tilde{f}_{j} \in \tilde{F}, j=1,2, \ldots,\right| \eta\right\}\right\}, \tilde{F} \subseteq \cap{ }_{F}{ }_{m}(\text { from } m=1 \text { to }|M|),
$$

consisting of sub-ensembles $\tilde{f}_{j}$ of significant informative signs which unambiguously determine impact of educational signals of some modality (audio, visual, synthetic, etc.).

In general case, set of informative signs of ensemble $\vec{F}_{m}$ for one educational subject does not provide completeness of various modal impacts, and learning of informative signs entering ensemble $F_{m+1}$ is necessary when studying the following subject, etc. until set of informative signs became sufficient for completeness of pattern of trainee internal representation.

This causes necessity of analysis for informative signs sequence $\stackrel{u}{F_{m}}, \stackrel{u}{F_{m+1}}, \stackrel{u}{F_{m+2}}, \ldots, \stackrel{u}{F_{m+k}}$ from k, beginning from the first, in which the informative sign is formulated.

In these conditions, ensembles $F_{m}$ и $\tilde{F}$ are also connected by relationship:

$$
\begin{aligned}
& \tilde{f}_{j}=\stackrel{u}{F_{m}} \mathrm{U}\left(\stackrel{u}{F_{m}} \cap \stackrel{u}{F_{m+1}}\right) \mathrm{U}\left(\stackrel{u}{F}_{m} \cap \stackrel{u}{F_{m+1}} \cap \stackrel{u}{F_{m+2}}\right) \mathrm{U} \ldots \mathrm{U} \cdot \\
& \left(\stackrel{u}{F_{m}} \cap \stackrel{u}{F}_{m+1} \cap \stackrel{u}{F}_{m+2} \cap \ldots \cap \stackrel{u}{F}_{m+k}\right) .
\end{aligned}
$$
$\leq m+k$.

Further we will express sequence (3) in the form of ensemble $S_{n}$, where $n$ - current length of the sequence, $m \leq n$

Besides, we will put ensemble:

$$
\dot{X}=\left\{\hat{x}_{j}\left(\tilde{\tilde{f}_{j}}\right)\left|\hat{x}_{j}\left(\tilde{\tilde{f}_{j}}\right) \in \dot{X}, j=1,2, \ldots,\right| \tilde{F} \mid\right\}
$$

of possible ways of significant informative signs implementation in correspondence with each sub-ensemble of these $\operatorname{signs} \tilde{f_{j}}$.

In general case, educational process can be formally represented as a process of change of the process information states $\bar{U}^{o}=\left(u_{1}^{o}, u_{2}^{o}, \ldots, u_{|Z|}^{o}\right)$ for creation of educational competences components and $\bar{U}^{m}=\left(u^{m}{ }_{1}, u^{m}{ }_{2}, \ldots\right.$, $\left.u_{|\dot{X}|}^{m}\right)$ process of creation of various modality educational signals which significantly influence expansion of trainee modal experience.

Assuming that, for implementation of information process $\bar{U}^{o}$, educational activities possess full time budgets, we will put time budget vector $\bar{O}^{o}=\left(q_{1}^{o}, q_{2}^{o}, \ldots, q_{i}^{o}, \ldots, q_{|Z|}^{o}\right)$ in correspondence with $\bar{U}^{o}$ information process. At that, to each element $q_{i}^{o}$, of temporary recourses vector ensemble $\bar{O}^{o}, F_{m}^{\prime}$ ensemble is put in correspondence and to each element $q^{m}{ }_{l}$ of ensemble $\bar{O}^{o}-$ one of elements of ensemble $\dot{X}$, i.e.:

$$
\begin{gathered}
\stackrel{u}{F_{m}}=\stackrel{u}{F_{m}}\left(q^{o} i\right), i=1,2, \ldots,|Z|, m=1,2, \ldots,|M|, \\
\dot{x}_{l}=\dot{x}_{l}\left(q^{m} l\right), l=1,2, \ldots,|\dot{X}| .
\end{gathered}
$$
equation:

Then creation by educational process of information state $z_{i}$ within an educational subject $y_{m}$ is described by the

when $\tilde{\tilde{f}}_{\mathrm{j}} \not \subset \mathrm{S}_{\mathrm{m}-\mathrm{k}}$,

$$
y_{m}\left(z_{i}\right)=u_{\mathrm{i}}^{o}\left(z_{i-1}\right) \cap u_{\mathrm{i}}^{m}\left({\stackrel{u}{F_{m}}}^{\prime}\right) \cap S_{n}
$$

and equation:

when $\tilde{\tilde{f}}_{\mathrm{j}} \subset \mathrm{S}_{\mathrm{m}-\mathrm{k}}$,

$$
\mathrm{y}_{\mathrm{m}}\left(\mathrm{z}_{\mathrm{i}}\right)=\dot{\mathrm{x}}_{\mathrm{j}}\left(\mathrm{S}_{\mathrm{n}}\right)
$$

Further, we will formally agree to understand $h_{\text {th }}$ variant of optimum control of individual creativity enhancement by expansion of trainee modal experience as certain data set $\mathrm{w}^{\mathrm{c}}{ }_{\mathrm{h}}\left(\overline{\mathrm{O}}^{\mathrm{m}}\right)$ characterizing distribution of elements of time budgets vector $\overline{\mathrm{O}}^{\mathrm{m}}$, and also methods of this resources realization for the benefit of information process $\overline{\mathrm{U}}^{\mathrm{m}}$.

Let us designate an ensemble of possible variants of such distributions

$$
W^{c}=\left\{W_{h}^{c}\left(\bar{O}^{m}\right)\left|W_{h}^{c}\left(\bar{O}^{m}\right) \in W^{c}, h=1,2, \ldots,\right| W^{c} \mid\right\},
$$


where $\left|W^{c}\right|$ - number of variants in ensemble $W^{c}$;

and value of polymodal creativity indicator for educational and methodical guidelines in educational process for variant $W_{h}^{c}\left(\bar{O}^{m}\right)$, requirements to quality of training and structure of educational process $\bar{S}$ as $q^{c}{ }_{8}\left(W_{h}^{c}\right)=E\left[\tilde{\mathrm{C}}, \tilde{S}, W_{h}^{c}\left(\bar{O}^{m}\right)\right]$.

Thus, the problem of optimum enhancement of individual creativity by expansion of trainee modal experience can be formulated as set of problems of synthesis of polymodal information processes for the benefit of enhancement of trainee individual creativity. This problem can be solved on the basis of methods of identification of educational activity time budgets, the recourses distribution between educational subjects and use for implementation of working training programs and curriculum for the purpose of maximizing $q_{8}^{c}\left(W_{h}^{c}\right)$ value on an ensemble (4). Formally it can be written down as following:

$$
q^{c}{ }_{8}\left[\tilde{\mathrm{C}}, \tilde{S}, W^{c}{ }_{h}\right] \rightarrow \max , W_{h}^{c} \in W^{c}, h=1,2, \ldots,\left|W^{c}\right| .
$$

Thus, optimal variant $W^{c}(o p t)$ is determined from formula:

$$
W_{(o p t)}^{c}=\arg \max q_{8}^{c}\left(W_{h}^{c}\right), W_{h}^{c} \in W^{c} .
$$

\section{Conclusion}

VI.

The obtained relationship will make it possible to solve some organizational and methodical problems in the course of educational process upgrade in various educational institutions for the purpose of individual creativity enhancement by expansion of trainee modal experience.

Some of such problems are:

optimum distribution of time budgets among specialization disciplines for the purpose of maximization of polymodal educational signals impact;

assessment of modal variety of educational signals of educational and methodical guidelines and their completeness within the educational module;

findings of variants of time budgets for application of various forms and methods of pedagogical impact in educational process, and some other.

Pedagogical study and adaptation of mentioned special tasks for specific educational institutions are directions for further researches.

The obtained ratio may be starting, for example, to find the optimum training time in distance learning [34], when the training data signals are implemented through information and communication technologies. Obviously, in a number of distance education modalities basic training signal is determined by the technical characteristics of computer hardware and peripheral equipment.

\section{Модель оптимизации образовательного процесса для развития индивидуальной креативности путем расширения модального опыта обучаемых}

\section{Е.А. Гафарова, В.А. Белевитин, Е.Н. Смирнов}

Аннотация. В статье рассмотрена модель оптимизации образовательного процесса по временному ресурсу для иелей развития креативности в процессе освоения обучающимися учебньх дисциплин. Направление развития креативности предполагается через расширение психофизиологического базиса обучаемого, то есть посредством максимального разнообразия модальности учебных сигналов. Задача оптимизации решена в общем виде при построении модели на основе информационных состояний в соответствии с принципами синергии форм информационного обеспечения образовательного прочесса и оптимального баланса временного ресурса и минимально необходимого для значимого повынения уровня развития креативности обучаемых. Решение оптимизации позволяет оценить разнообразие модальности учебных сигналов учебно-методического обеспечения, их полноту в рамках учебного модуля, найти варианть использования временного ресурса при применении различных форм и методов педагогического воздействия в учебном nроцессе.

Ключевые слова: развитие креативности, расширение модального опьта, информационные состояния, паттернь внутренней репрезентации, модальности учебных сигналов. 


\title{
Модель оптимізації освітнього процесу для розвитку індивідуальної креативності шляхом розширення модального досвіду осіб що навчаються
}

\author{
О.А. Гафарова, В.А. Белевітін, С.М. Смирнов
}

\begin{abstract}
Анотація. В статті розглянута модель оптимізації освітнього процесу щодо часового ресурсу для розвитку креативності у процесі засвоєння навчальних дисииплін особами, щз навчаються. Розвиток креативності передбачається завдяки розширенню психофізіологічного базиса особи, яка навчається, тобто завдяки максимальній різноманітності модальності навчальних сигналів. Задача оптимізації розв'язана у загальному випадку при побудові моделі на основі інформаційних станів у відповідності з принципами синергії форм інформаційного забезпечення освітнього процесу $i$ оптимального балансу часового ресурсу та мінімально необхідного для значного підвищення рівня розвитку креативності осіб, щзо навчаються. Розв'язок оптимізачії дозволяе оцінити різноманітність модальності навчальних сигналів навчальнометодичного забезпечення, їх повноту в рамках навчального модуля, знайти варіанти використання часового ресурсу під час використання різних форм і методів педагогічного впливу у навчальному процесі.
\end{abstract}

Ключові слова: розвиток креативності, розширення модального досвіду, інформаційні стани, патерни внутрішньоі репрезентачіï, модальності навчальних сигналів.

\section{References}

1. Dorfman, L.Ya. and Dorfman, L.Ya. (2014), Martindeyl Theory of creativity, Psychology issues: Publishing house LLC Voprosy psikhologii, Moscow, No. 4, pp. 126-134.

2. Dorfman, L.Ya. and Dorfman L.Ya. (2015), Levels and types of creativity: analysis of modern psychological concepts, Psychological journal: Publishing house "Nauka", Vol. 36, No. 1, pp. 81-90.

3. Li, Y.-H., Tseng, C.-Y., Huang, A.C.-W., Lin, W.-L. and Tsai, A.C.-H. (2016), Different brain wave patterns and cortical control abilities in relation to different creative potentials, Creativity Research Journal, Vol. 28, no 1, pp. 89-98.

4. Kholodnaya, M.A. (2011), All-Russian scientific conference "Intelligence and creativity: scientific traditions and modern approaches", Psychological journal, Vol. 32, No. 3, pp. 137-139.

5. Razumnikova, O.M. and Volf, N.V. (2015), Creativity-Related hemispheric selective processing: correalations on globaland local levels of attentional set, Creativity Research Journal, Vol. 27, No. 4, pp. 394-399,

http://dx.doi.org/10.1080/10400419.2015.1087272.

6. Kostromina, S.N., Bordovskaya, N.V. Iskra, N.N. and Chuvgunova, O.A. (2015), Neurosciences, psychology and education: problems and prospects of cross-disciplinary researches, Psychological journal: Publishing house "Nauka", Vol. 36, No. 4, pp. 61-70.

7. Ozhiganova, G.V. (2015), International scientific and practical seminar "Technology of diagnostics and activation of mental resources", Psychological journal: Publishing house "Nauka", Vol. 36, No. 3, pp. 100-102.

8. Kholodnaya, M.A. (2015), Intellect, creativity, learning ability: resource approach (About development of ideas of V. N. Druzhinin), Psychological journal: Publishing house "Nauka", Vol. 36, No. 5, pp. 5-14.

9. Gasimova, V.A. and Dorfman, L.Ya. (2014), Relation between creative thinking of psychometric intelligence and speed of information processing in the conditions of focused and unfocused concentration, Proceedings of International scientific and practical conference "Prospects of Development of Science and Education", Publishing house: LLC Consulting Company Yukom, Tambov, pp. 41-42.

10. Pinheiro, I.R. and Cruz, R.M. (2014), Mapping creative: creativity measurements network analysis, Creativity Research Journal, Vol. 26, No. 3, pp. 263-275.

11. Jaussi, K.S. and Randel, A.E. (2014), Where to look? Creativite self-efficacy, knowledge retrieval and incremental and radical creativity, Creativity Research Journal, Vol. 26, No. 4, pp. 400-410, http://dx.doi.org/10.1080/10400419.2014.961772.

12. Herrmann, D. and Felfe, J. (2013), Moderators of the relationship between leadership style and employee creativity: the role of task novelty and personal initiative, Creativity Research Journal, Vol. 25, No. 2, pp. 172-181, http://dx.doi.org/10.1080/10400419.2013.783743.

13. Kholodnaya, M.A. and Scherbakova, O.V. (2013), Information and energy characteristics of various types of cognitive activities, Psychological journal: Publishing house "Nauka", No. 5, pp. 96-107.

14. Atanov, M.S., Ivanitsky, G.A. and Ivanitsky, A.M. (2016), Cognitive interface brain-computer and prospects of its practical use, Human physiology: Publishing house "Nauka", Vol.42, No. 3, pp. 5-15.

15. Shen, W., Liu, C., Zhang, X., Zhang, J., Yuan, Y., Chen, Y. and Zhao, X. (2013), Right hemispheric dominance of creative insight: an event-related potential study, Creativity Research Journal, Vol. 25, No. 1, pp. 48-58.

16. Pavlov, A.V. (2012), Algebra of dual Fourier transforms: logic with exclusion, Artificial intelligence and decision making: Publishing house: Federal research center "Informatics and Management" of the Russian Academy of Sciences, No. 3, pp. 26-38.

17. Pavlov, A.V. (2008), About possibility of Fourier-holography application in simulation of creative thinking: requirements to transfer characteristics of reversive holographic environments, Journal of Optical Technology: Publishing house: St. Petersburg national research university of information technologies, mechanics and optics, Vol.75, No. 10, pp. 42-49.

18. Gafarova, E.A. (2016), Enhancement of creativity by expansion of variety of trainee modal experience, Discussion, No. 6 (69), pp. 121-130. 
19. EC (2000), Communication from the Commission: E-Learning - Designing “Tejas at Niit” tomorrow's education, Brussels: European Commission.

20. Allen, E. and Seaman, J. (2011), Going the distance: Online education in the United States, Babson Park, MA: Babson Survey Research Group.

21. Hebert, D.G. (2007), Five Challenges and Solutions in Online Music Teacher Education, Research and Issues in Music Education, No. 5 (1), pp. 1-10.

22. Zhang, D. Zhou, L., Briggs, R.O. Nunamaker Jr, J.F. (2006), Instructional video in e-learning: Assessing the impact of interactive video on learning effectiveness, Information \& Management, No. 43(1), pp. 15-27, URL: http://dx.doi.org/10.1016/j.im.2005. 01.004 .

23. Krause, U.M., Stark, R. and Mandl, H. (2009), The effects of cooperative learning and feedback on e-learning in statistics, Learning and Instruction, No. 19(2), pp. 158-170, DOI: http://dx. doi.org/10.1016/j. learninstruc.2008.03.003.

24. Palacios-Marqués, D., Cortés-Grao, R. and Lobato-Carral, C., (2013), Outstanding knowledge competences and web 2.0 practices for developing successful e-learning project management, International Journal of Project Management, No. 31(1), pp. 14-21, DOI: http://dx.doi.org/10.1016/j.ijproman.2012.08.002.

25. Shaidullin, R.N., Safiullin, L.N., Gafurov, I.R. and Safiullin, N.Z. (2014), Blended Learning: Leading Modern Educational Technologies, Procedia-Social and Behavioral Sciences, No. 131, pp. 105-110, DOI: http://dx.doi.org/10.1016/j.sbspro.2014.04.087.

26. Gnatyshina, E.A., Bogatenkov, S.A., Gnatyshina, E.V. and Uvarina, N.V. (2015), Informacionnaja podgotovka pedagogov professional'nogo obuchenija v aspekte bezopasnosti, monografija, Izd-vo Cheljab. gos. ped. un-ta, Cheljabinsk, Russia.

27. Ivanko, E.E. (2013), Dynamic programming me thod in minimax problem of tasks distribution among equivalent performers, Bulletin of Southern Ural State University, Series: Mathematical Modelling, Programming \& Computer Software, Southern Ural State University (national research university) (Chelyabinsk), Vol. 6, No. 1, pp. 124-130.

28. Karminskaya, T.D., Kovalyov, V.Z., Tsiporin, P.I. and Arkhipova O.V. (2010), Numerical optimization method of resources distribution for system of educational institutions, Bulletin of the Yugra state university, No. 4 (19), URL: http://cyberleninka.ru/ article/n/chislennyy-metod-optimizatsii-raspredeleniya-resursov-dlya-sistemy-obrazovatelnyhuchrezhdeniy (date of the address: 24.11.2016).

29. Moryeva, N. (2013), Optimization of educational process in the conditions of modernization of Russian education, Science and school, No. 3, URL: http://cyberleninka.ru/article/n/ optimizatsiya-uchebnogo-protsessa-v-usloviyah-modenizatsiirossiyskogo-obrazova-niya (date of the address: 11/24/2016).

30. Mitrofanov, A.A. (2011), One method for optimization of distinguishing signs selection at limited resources, SGTU Bulletin, No. 1, URL: http://cyberleninka.ru/article/n/ob-odnom-metode-optimizatsii-vybora-raspoznayuschih-priznakov-priogranichennyh-resursah (date of the address: 11/27/2016).

31. Zakharov, E.V. and Zimozdra, R.E. (2014), Limits of applicability of a spherical model for solving, problems of electroencephalography, Moscow University Computational Mathematics and Cybernetics, vol. 38. no 3, pp. 100-104.

32. Urazov, A.S. (2013), Optimum parameters of hierarchical control structures, Moscow, University, Computational, Mathematics and Cybernetics, Vol. 37, No. 1, pp. 14-20.

33. Kostomarov, D.P., Zaitsev, F.S., Luk'yanitsa, A.A., Shishkin, A.G., Anikeev, F.A. and Zlobin, V.V. (2013), The NNTMM code mathematical modeling, optimi-zationand data analysis through neural networks, Moscow University Computational Mathematics and Cybernetics, Vol. 37, No. 2, pp. 55-60.

34. Yeh, Y.C. and Lin, C.F. (2015), Aptitude-Treatment Interactions During Creativity Training in E-learning: How MeaningMaking, Self-Regulation, and Knowledge Management Influence Creativity, Education Technology and Society, Vol. 18, No. 1, pp. 119-131. 